\title{
Redox Probing Study of the Potential Dependence of Charge Transport Through Li2O2
}

\author{
Knudsen, Kristian Bastholm; Luntz, Alan C.; Jensen, Søren Højgaard; Vegge, Tejs; Hjelm, Johan
}

Published in:

The Journal of Physical Chemistry Part C

Link to article, DOI:

10.1021/acs.jpcc.5b08757

Publication date:

2015

Document Version

Publisher's PDF, also known as Version of record

Link back to DTU Orbit

Citation (APA):

Knudsen, K. B., Luntz, A. C., Jensen, S. H., Vegge, T., \& Hjelm, J. (2015). Redox Probing Study of the Potential Dependence of Charge Transport Through $\mathrm{Li}_{2} \mathrm{O}$. The Journal of Physical Chemistry Part C, 119(51), 28292-28299. https://doi.org/10.1021/acs.jpce.5B08757

\section{General rights}

Copyright and moral rights for the publications made accessible in the public portal are retained by the authors and/or other copyright owners and it is a condition of accessing publications that users recognise and abide by the legal requirements associated with these rights.

- Users may download and print one copy of any publication from the public portal for the purpose of private study or research.

- You may not further distribute the material or use it for any profit-making activity or commercial gain

- You may freely distribute the URL identifying the publication in the public portal 


\title{
Redox Probing Study of the Potential Dependence of Charge Transport Through $\mathrm{Li}_{2} \mathrm{O}_{2}$
}

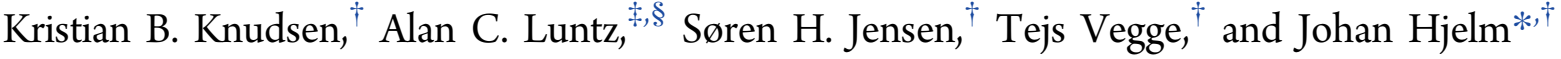 \\ ${ }^{\dagger}$ Department of Energy Conversion and Storage, Technical University of Denmark, 4000 Roskilde, Denmark \\ ${ }^{\ddagger}$ SUNCAT Center for Interface Science and Catalysis, Department of Chemical Engineering, Stanford University, 443 Via Ortega, \\ Stanford, California 94305-5025, United States \\ ${ }^{\S}$ SLAC National Accelerator Laboratory, 2575 Sand Hill Road, Menlo Park, California 94025, United States
}

Supporting Information

ABSTRACT: In the field of energy storage devices the pursuit for cheap, high energy density, reliable secondary batteries is at the top of the agenda. The $\mathrm{Li}-\mathrm{O}_{2}$ battery is one of the possible technologies that, in theory, should be able to close the gap, which exists between the present state-of-the-art Liion technologies and the demand placed on batteries by technologies such as electrical vehicles. Here we present a redox probing study of the charge transfer across the main deposition product lithium peroxide, $\mathrm{Li}_{2} \mathrm{O}_{2}$, in the $\mathrm{Li}-\mathrm{O}_{2}$ battery using outer-sphere redox shuttles. The change in heterogeneous electron transfer exchange rate as a function of the potential and the $\mathrm{Li}_{2} \mathrm{O}_{2}$ layer thickness ( depth-of-discharge) was determined using electrochemical impedance spectroscopy. The attenuation of the electron transfer exchange rate with film thickness is dependent on the probing potential, providing evidence that hole transport is the dominant process for

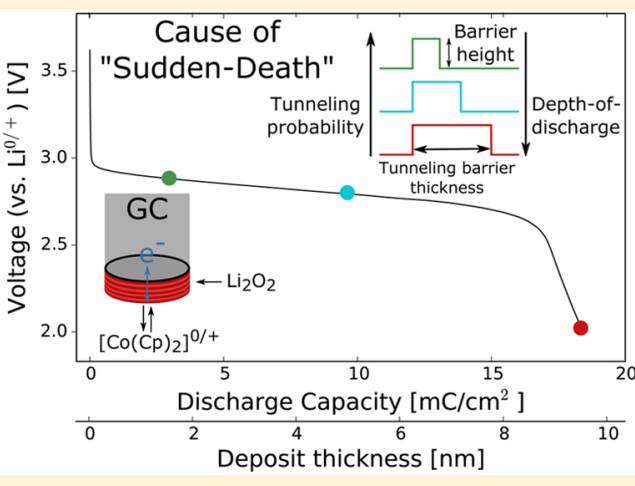
charge transfer through $\mathrm{Li}_{2} \mathrm{O}_{2}$ and showing that the origin of the sudden death observed upon discharge is due to charge transport limitations.

\section{INTRODUCTION}

The $\mathrm{Li}-\mathrm{O}_{2}$ battery is, in theory at least, a prime candidate for the ultimate generation of beyond Li-ion chemistries, as the theoretical specific energy and energy density for a fully charged battery is $11400 \mathrm{Wh} / \mathrm{kg}$ and $6080 \mathrm{Wh} / \mathrm{L}$, respectively. ${ }^{1}$ In the $\mathrm{Li}-\mathrm{O}_{2}$ battery, the net electrochemical reaction is $2 \mathrm{Li}+\mathrm{O}_{2} \leftrightarrows$ $\mathrm{Li}_{2} \mathrm{O}_{2}$, with the forward reaction corresponding to discharge and the reverse direction to charge. Realizing a practical specific energy of even $1000 \mathrm{Wh} / \mathrm{kg}$ with this cell chemistry still requires tremendous efforts in surmounting existing challenges. ${ }^{2}$

One of the pressing problems is the lack of a fully stable electrolyte during discharge and charge, and this severely limits cycle life. $^{3-8}$ Another challenge is the development of a chemically and electrochemically stable cathode since carbon has been shown to not be fully stable..$^{9-11}$ In addition, the charging overpotentials are quite high, although the reasons for this are still controversial. ${ }^{2}$ Finally, the discharge capacity is much smaller than anticipated from complete filling of the pore volume of the cathode. To understand the last challenge requires knowledge of the mechanisms of deposition of the main discharge product, $\mathrm{Li}_{2} \mathrm{O}_{2}$.

In general, $\mathrm{Li}_{2} \mathrm{O}_{2}$ forms as either toroidal-shaped particles or conformally deposited continuous and dense films on the cathode surface and are referred to as either the solution- or the surface-based mechanism. ${ }^{3,12,13}$ While the surface electrochemistry always occurs on the cathode, the solution mechanism becomes important when the intermediate $\mathrm{LiO}_{2}$ is soluble in the electrolyte. The solubility is described well by the electrolyte's donor and acceptor numbers as descriptors for describing the free energy of solution of the $\mathrm{Li}^{+}$ion and superoxide, $\mathrm{O}_{2}{ }^{-}$, respectively. Ultimately the reaction $\mathrm{Li}^{+}+\mathrm{O}_{2}{ }^{-}$ $\leftrightarrows \mathrm{LiO}_{2}$ followed by $2 \mathrm{LiO}_{2} \rightarrow \mathrm{Li}_{2} \mathrm{O}_{2}+\mathrm{O}_{2}$ takes place to form toroids. ${ }^{3,13,14}$ The extent to which these mechanisms dominates the cell electrochemistry has a significant impact on the discharge capacity as higher capacities have been reported when toroids are formed. ${ }^{3,4,13,14}$ It was shown by Aetukuri et al. ${ }^{3}$ that in a rigorously anhydrous electrolyte based on 1,2-dimethoxyethane as the solvent no toroids were formed unless some $\mathrm{H}_{2} \mathrm{O}$ is added. It was suggested that this solvent does not have a high enough donor number and acceptor number to give significant solubility of $\mathrm{LiO}_{2}$. On the other hand, higher donor number anhydrous solvents can produce toroids. ${ }^{3,13,15}$

However, independent of the mechanism eventually a sudden drop in potential (sudden death) occurs from the increasing ohmic losses through the formed $\mathrm{Li}_{2} \mathrm{O}_{2} .{ }^{16}$ It has been argued that the origin of this sudden death is due to charge transport through the discharge product $\mathrm{Li}_{2} \mathrm{O}_{2}$ as $\mathrm{Li}_{2} \mathrm{O}_{2}$ is a high-band-gap insulator. ${ }^{17}$ Viswanathan et al. ${ }^{18}$ suggested that sudden death occurs when a hole tunneling current

Received: September 8, 2015

Revised: November 19, 2015 
through $\mathrm{Li}_{2} \mathrm{O}_{2}$ films cannot support the electrochemical current any longer. They studied the charge transport through various film thicknesses of $\mathrm{Li}_{2} \mathrm{O}_{2}$ using a ferrocene/ferroceniuim redox probe and analyzed the results using a first-principles charge transport model.

In this paper, we present a more extensive redox probing study of the electron conduction through thin and dense $\mathrm{Li}_{2} \mathrm{O}_{2}$ layers on glassy carbon electrodes. We set out to expand on the work by Viswanathan et al. ${ }^{18}$ by investigating the potential dependence of the attenuation of charge transfer through the $\mathrm{Li}_{2} \mathrm{O}_{2}$ layer in order to shed more light on the mechanism of this important process. Three different outer-sphere redox shuttles were used to probe the charge transport through $\mathrm{Li}_{2} \mathrm{O}_{2}$ at three different potentials, corresponding closely to the standard reduction potential of each redox couple. The selected redox shuttles are cobaltocene/cobaltocenium $\left(\left[\mathrm{Co}(\mathrm{Cp})_{2}\right]^{0 /+}\right)$, decamethylferrocene/decamethylferrocenium ([Fe$\left.\left.(\mathrm{DMCp})_{2}\right]^{0 /+}\right)$, and ferrocene/ferroceniuim $\left(\left[\mathrm{Fe}(\mathrm{Cp})_{2}\right]^{0 /+}\right)$. These redox shuttles were used since (i) they are relatively stable and known to display facile interfacial electron exchange kinetics, yielding a reversible electrochemical response, ${ }^{19-21}$ and (ii) as illustrated in Figure 1, they ensure that a wide

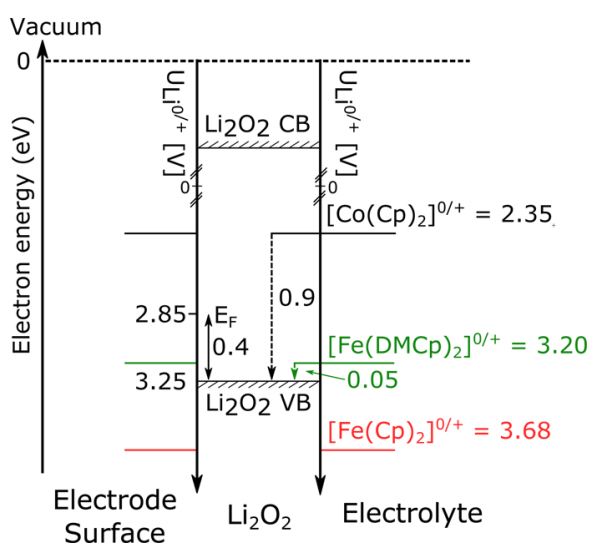

Figure 1. Sketch of the electronic structure for $\mathrm{Li}_{2} \mathrm{O}_{2}{ }^{23,24}$ relative to the energy levels of the three redox shuttle pairs, which were determined from the $E_{1 / 2}$ calculated from measured cyclic voltammograms. The charge-transfer process across the $\mathrm{Li}_{2} \mathrm{O}_{2}$ has been illustrated analogously to a metal-insulator-metal junction and shows the hole tunneling barriers for $\left[\mathrm{Co}(\mathrm{Cp})_{2}\right]^{0 /+}$ and $[\mathrm{Fe}-$ $\left.(\mathrm{DMCp})_{2}\right]^{0 /+}$ as 0.9 and $0.05 \mathrm{~V}$, respectively, while $\left[\mathrm{Fe}(\mathrm{Cp})_{2}\right]^{0 /+}$ is inside the valence band with a half-wave potential $\left(E_{1 / 2}\right)$ of $3.68 \mathrm{~V}$. When the charge-transfer process through $\mathrm{Li}_{2} \mathrm{O}_{2}$ is investigated the potential of the electrode is held at $E_{1 / 2}$ of the redox shuttle, which is illustrated with energy levels on the "electrode surface" side.

potential window could be probed relative to the valence (VB) and conduction band (CB) of the wide band gap of $\mathrm{Li}_{2} \mathrm{O}_{2}$. The band gap of $\mathrm{Li}_{2} \mathrm{O}_{2}$ has been estimated to lie within $5.15-6.37$ $\mathrm{eV}, 22$ and as the $\mathrm{VB}$ of $\mathrm{Li}_{2} \mathrm{O}_{2}$ is only $\sim 0.4 \mathrm{~V}$ higher than the Fermi level, ${ }^{23} E_{\mathrm{F}}$, the $\mathrm{CB}$ must therefore lie at very high energies $\mathrm{vs}^{\mathrm{O}}{ }^{\mathrm{O}+}$, as sketched in Figure 1 . The alignment of the $\mathrm{VB}$ relative to the $\mathrm{Li}^{0 /+}$ potential is based on that suggested in refs 23 and 24 where the VB is pinned. Therefore, electron conduction is extremely unlikely. Even electron polarons, which are $\sim 2 \mathrm{eV}$ below the $\mathrm{CB}$, have very high barriers to diffusion and cannot conduct charge readily. ${ }^{25}$ Hence, experiments with $\left[\mathrm{Co}(\mathrm{Cp})_{2}\right]^{0 /+}$ and $\left[\mathrm{Fe}(\mathrm{DMCp})_{2}\right]^{0 /+}$ probe the conduction path of holes, either by hole tunneling or via localized hole polarons, ${ }^{26}$ since their potentials are deep inside the band gap of $\mathrm{Li}_{2} \mathrm{O}_{2}$, while $\left[\mathrm{Fe}(\mathrm{Cp})_{2}\right]^{0 /+}$ is inside the $\mathrm{VB}$ where some other resistive conduction dominates. In principal, both hole tunneling and hole polaron hopping can coexist for charge transport. ${ }^{24}$ However, the dominant effect estimated theoretically is a modest reduction in the tunneling current due to the localized holes in the tunneling regime. ${ }^{23}$

\section{EXPERIMENTAL SECTION}

2.1. Materials. Bis(trifluoromethane)sulfonamide lithium salt (LiTFSI), tetrabutylammonium perchlorate $\left(\mathrm{TBAClO}_{4}\right)$, $\left[\mathrm{Fe}(\mathrm{Cp})_{2}\right]^{0},\left[\mathrm{Fe}(\mathrm{Cp})_{2}\right]^{+} \mathrm{PF}_{6}^{-},\left[\mathrm{Co}(\mathrm{Cp})_{2}\right]^{0},\left[\mathrm{Co}(\mathrm{Cp})_{2}\right]^{+} \mathrm{PF}_{6}^{-}$, $\left[\mathrm{Fe}(\mathrm{DMCp})_{2}\right]^{0}$, dichloromethane, trifluoroacetic acid, ammonium hexafluorophosphate (99.99\%), acetonitrile, and $4 \AA$ molecular sieves were purchased from Sigma-Aldrich. 1,2Dimethoxyethane (DME) was purchased from BASF and dried over $4 \AA$ molecular sieves that had been dried at $230{ }^{\circ} \mathrm{C}$ under vacuum, inside a glovebox. $\left[\mathrm{Fe}(\mathrm{DMCp})_{2}\right]^{+} \mathrm{PF}_{6}{ }^{-}$was, to the best of our knowledge, not commercially available and therefore synthesized. This work is reported in the Supporting Information, Figure S1.

2.2. Electrochemical Experiments. All electrochemical investigations where conducted at $25{ }^{\circ} \mathrm{C}$, and the electrochemical cells were assembled in an Ar-filled glovebox with $\mathrm{O}_{2}$ and $\mathrm{H}_{2} \mathrm{O}$ levels maintained below $2 \mathrm{ppm}$. Electrochemical cells were assembled with four working electrodes, a Pt counter electrode, and a dual-reference electrode consisting of a doublejunction $\mathrm{Ag} / 0.01 \mathrm{M} \mathrm{AgNO}_{3}-1 \mathrm{M}$ LiTFSI-DME//1 M LiTFSI-DME// in parallel with a $0.1 \mu \mathrm{F}$ capacitor connected to a second $\mathrm{Pt}$ wire in solution. This reference electrode maintains a stable dc potential at all times from the $\mathrm{Ag} / \mathrm{AgNO}$ part and thanks to the high-frequency bypass Pt-wire makes it possible to obtain high-quality electrochemical impedance also at high $(f>\sim 100 \mathrm{~Hz})$ frequencies. Use of a similar RE has previously been reported in refs 27-29. All current densities were calculated using the geometric area of the respective electrode. The electrolyte was $1 \mathrm{M}$ LiTFSI-DME, where LiTFSI was dried in vacuum at $180{ }^{\circ} \mathrm{C}$ for $12 \mathrm{~h}$. The cell contained three $(d=1.6 \mathrm{~mm})$ working glassy carbon (GC) disk embedded electrodes and one $(d=1.6 \mathrm{~mm})$ Au disk embedded electrode in polyether ether ketone (PEEK) resin from BioLogic, which were all polished using aqueous suspensions of $0.05 \mu \mathrm{m}$ aluminum oxide (MicroPolish, Buehler). After assembly, the electrochemical cell was transferred out of the glovebox with minimal exposure to ambient conditions, placed in a Faraday cage, and flushed with $\mathrm{O}_{2}$ or $\mathrm{Ar}$ that passed through $4 \AA$ molecular sieves followed by dried DME before entering the cell to minimize water impurities. Increases in the $\mathrm{H}_{2} \mathrm{O}$ and $\mathrm{O}_{2}$ levels were monitored by examining the cyclic voltammogram of an $\mathrm{Au}$ electrode immersed in the electrolyte, and experiments with increasing levels of $\mathrm{H}_{2} \mathrm{O}$ were discarded. All electrochemical experiments were performed using a SP-200 Bio-Logic potentiostat or a Gamry REF600.

The diffusion coefficients of $\left[\mathrm{Co}(\mathrm{Cp})_{2}\right]^{0 /+},\left[\mathrm{Fe}(\mathrm{DMCp})_{2}\right]^{0 /+}$, and $\left[\mathrm{Fe}(\mathrm{Cp})_{2}\right]^{0 /+}$ in $1 \mathrm{M}$ LiTFSI-DME were determined by using the Randles-Sevcik method on a $(d=1.6 \mathrm{~mm}) \mathrm{GC}$ electrode. These experiments were conducted in Ar-saturated electrolyte using the previously described cell.

$\mathrm{Li}_{2} \mathrm{O}_{2}$ was deposited in $\mathrm{O}_{2}$-saturated $1 \mathrm{M}$ LiTFSI-DME with a continuous flow of dry $\mathrm{O}_{2}$ as atmosphere. The deposition was performed galvanostatically at a current density of $2.5 \mu \mathrm{A} / \mathrm{cm}^{2}$. The electrodes were discharged sequentially to a given depth of discharge ( $\sim \mathrm{Li}_{2} \mathrm{O}_{2}$ film thickness). Subsequently, dissolved oxygen was removed from the electrolyte by purging the 
electrolyte with $\mathrm{Ar}$ until $\mathrm{O}_{2}$ could no longer be detected on the Au electrode. A blanket of Ar was maintained over the solution after purging. Then a $1 \mathrm{mM}$ stock solution of each redox shuttle pair, with a supporting $1 \mathrm{M}$ LiTFSI-DME electrolyte, was added, and subsequently, the cell was purged again with Ar to ensure inert conditions. The concentration of the redox shuttle in solution was determined by the $\mathrm{Au}$ electrode by the peak current in a cyclic voltammogram, which ranged from 0.02 to $0.05 \mathrm{mM}$. The charge transport through $\mathrm{Li}_{2} \mathrm{O}_{2}$, deposited on each GC electrode, was probed by measuring the chargetransfer resistance $\left(R_{\mathrm{CT}}\right)$ of each redox shuttle as a function of the depth of discharge (i.e., the $\mathrm{Li}_{2} \mathrm{O}_{2}$ film thickness) by performing electrochemical impedance spectroscopy at $E_{1 / 2}$ of the redox shuttle in the electrolyte. Electrochemical impedance spectroscopy (EIS) was measured using an ac amplitude of 10 $\mathrm{mV}$ over the frequency range from $100 \mathrm{kHz}$ to $1 \mathrm{~Hz}$ with 12 points/decade and 2 cycles/frequency. The procedure was conducted for each of the three redox shuttles. A sketch of the experimental setup is given in Figure 2.

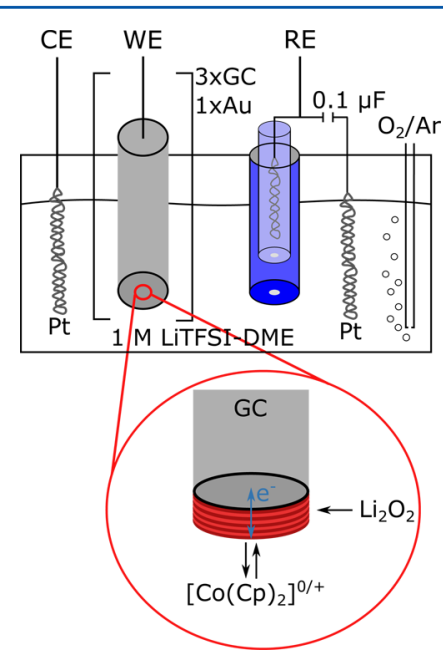

Figure 2. Schematic diagram of the experimental setup using $\left[\mathrm{Co}(\mathrm{Cp})_{2}\right]^{0 /+}$ to probe the charge transfer at three different electrodes, each with a certain thickness of $\mathrm{Li}_{2} \mathrm{O}_{2}$. WE stands for working electrode, $\mathrm{CE}$ for counter electrode, and $\mathrm{RE}$ for reference electrode.

\section{RESULTS AND DISCUSSION}

3.1. Electrolyte Water Content Monitoring. Ensuring a water-free environment for any nonaqueous metal-air system is crucial, as multiple reports $3,4,13-15,30$ have shown that water and different anions will replace DME in the solvation shell of $\mathrm{Li}^{+}$, thus increasing the capacity of the cell, not only by the extra faradaic route of water reduction but more importantly by activating a solution-based mechanism for $\mathrm{Li}_{2} \mathrm{O}_{2}$ formation that in turn can cause the deposition of toroid-shaped $\mathrm{Li}_{2} \mathrm{O}_{2}$ on the electrode surface. ${ }^{3,4,13-15,30}$ LiTFSI was therefore dried at 180 ${ }^{\circ} \mathrm{C}$ for a minimum of $12 \mathrm{~h}$ in vacuum, and the effect is illustrated in Figure S2. The voltammograms stress the importance of using a dry salt. ${ }^{5}$ Due to high Li salt content in the electrolyte a small water impurity in the salt may still influence the potential window of the electrolyte solution significantly as seen in Figure S2. It should also be stressed that significant water reduction is not observed on GC surfaces in the investigated potential range due to a too low exchange current density, and other materials such as $\mathrm{Au}$ or (better) $\mathrm{Pt}$ can be used for this purpose. In this study, a Au electrode was used to monitor changes in the water content (and other electrochemically active impurities) of the electrolyte.

3.2. Voltammetry of the Redox Shuttles. The half-wave potentials, reversibility, and diffusion coefficients of the redox shuttles used in this study were determined using cyclic voltammetry. The diffusion coefficients were used to make concentration determinations in conjunction with the redox probing experiments reported later in this manuscript. The voltammetry of the redox shuttles in $1 \mathrm{M} \mathrm{LiTFSI}$ in DME was studied using GC electrodes. All voltammograms have been IR corrected by determining the series resistance using EIS and correcting the voltage for the resistive drop $(U=I \cdot R)$. A summary of the voltammograms for the three redox shuttles is given in Figure 3 and illustrates the reasoning behind the choice

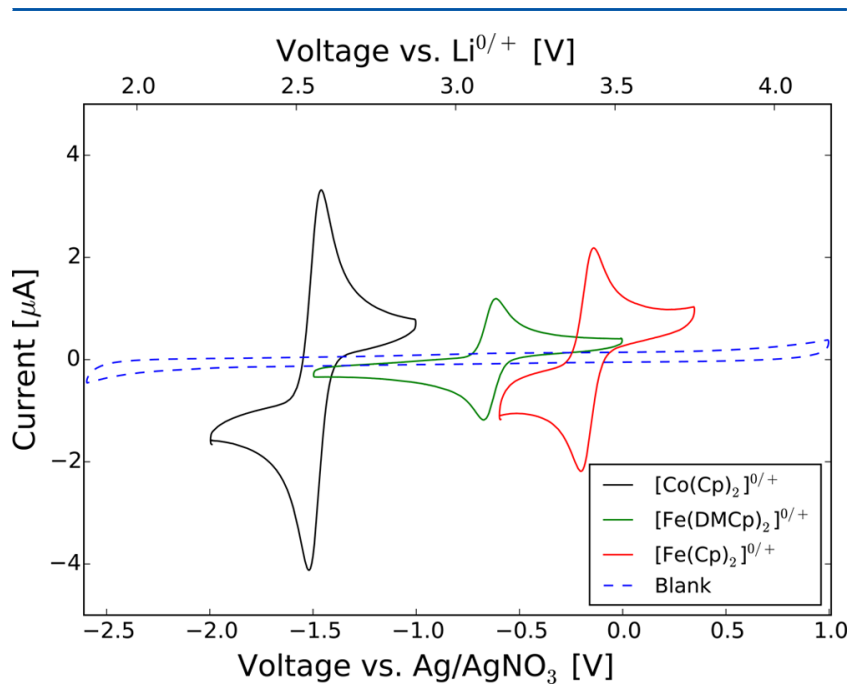

Figure 3. Cyclic voltammograms recorded at a scan rate of $100 \mathrm{mV} / \mathrm{s}$ of the three different redox shuttles, $\left[\mathrm{Co}(\mathrm{Cp})_{2}\right]^{0 /+},\left[\mathrm{Fe}(\mathrm{DMCp})_{2}\right]^{0 /+}$, and $\left[\mathrm{Fe}(\mathrm{Cp})_{2}\right]^{0 /+}$, and including a blank scan. All four voltammograms where recorded in Ar-saturated 1 M LiTFSI-DME and have been IR corrected. Note that only one of the redox shuttles was present in solution at any given time.

of these three shuttles as they span a potential window of $\sim 1.3$ $\mathrm{V}\left(2.35-3.68 \mathrm{~V}\right.$ vs $\left.\mathrm{Li}^{0 /+}\right)$, where each species was present in approximately equimolar amounts.

The electrochemical reversibility of the three redox shuttles was evaluated in the scan rate interval of $10-1000 \mathrm{mV} / \mathrm{s}$ based on the peak potential separation between the anodic and the cathodic peak potentials $\left(\Delta E_{\mathrm{p}}\right)$. Figure 4 depicts the voltammograms of $\left[\mathrm{Co}(\mathrm{Cp})_{2}\right]^{0 /+}$ as a function of scan rate $(\nu)$, and the Randles-Sevcik plot $\left(I_{\text {peak }}\right.$ vs $\left.\nu^{1 / 2}\right)$ was used to determine the diffusion coefficients for the two species, e.g., the neutral and positive species of the redox shuttle in solution. For $\left[\mathrm{Co}(\mathrm{Cp})_{2}\right]^{0 /+}, \Delta E_{\mathrm{p}}$ ranged from 51 to $64 \mathrm{mV}$ with an average of $57.14 \pm 4.43 \mathrm{mV}$, which is in close agreement with the theoretical value of $56.50 \mathrm{mV}$ for a one-electron process. ${ }^{31}$ The corresponding plots for $\left[\mathrm{Fe}(\mathrm{DMCp})_{2}\right]^{0 /+}$ and $\left[\mathrm{Fe}(\mathrm{Cp})_{2}\right]^{0 /+}$ are illustrated in Figure $S 3$, where $\Delta E_{\mathrm{p}}$ ranged from 62 to 72 and 61 to $72 \mathrm{mV}$, respectively. A detailed report of the electrochemical reversibility is given in Tables $\mathrm{S} 1-\mathrm{S} 3$.

The diffusion coefficients of $\left[\mathrm{Co}(\mathrm{Cp})_{2}\right]^{0 /+},\left[\mathrm{Fe}(\mathrm{DMCp})_{2}\right]^{0 /+}$, and $\left[\mathrm{Fe}(\mathrm{Cp})_{2}\right]^{0 /+}$ were determined by the Randles-Sevcik equation, eq 1 , that describes the relationship between peak currents $\left(I_{\mathrm{p}}\right)$ and scan rate $(\nu)$ of a reversible electrochemical reaction under semi-infinite linear diffusion conditions 

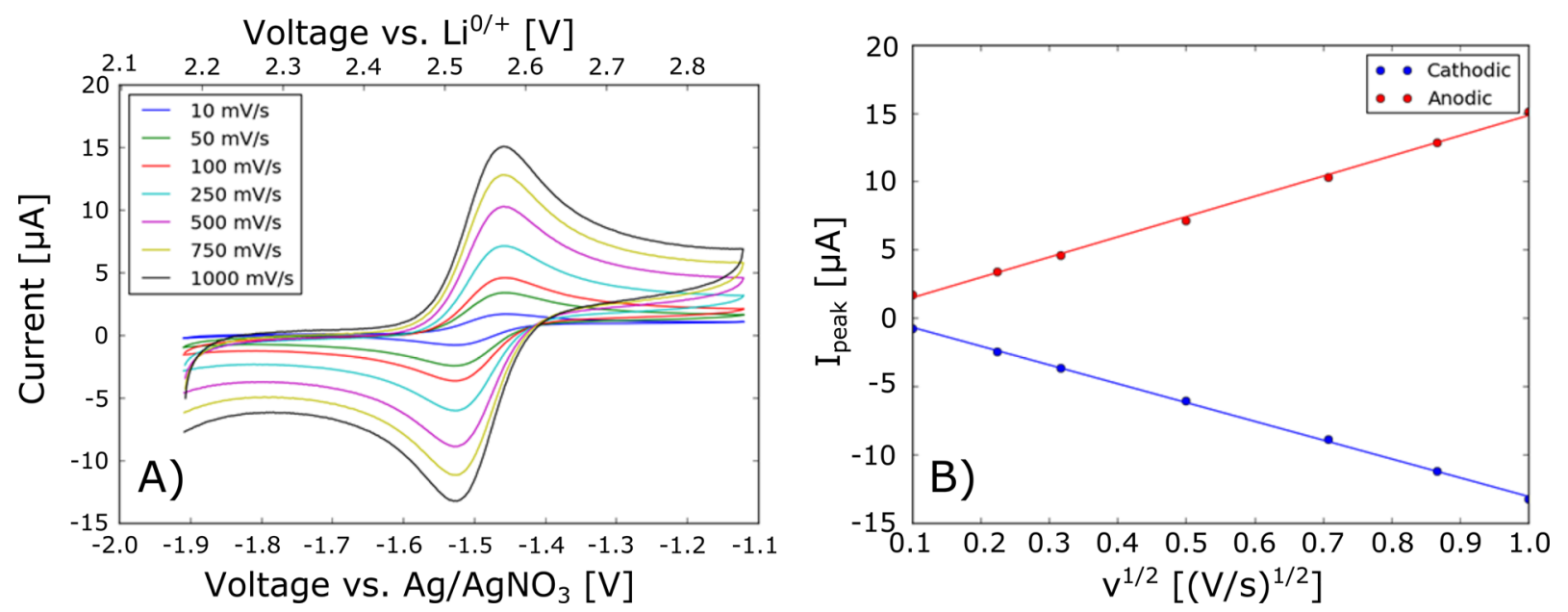

Figure 4. (A) Cyclic voltammogram of $\left[\mathrm{Co}(\mathrm{Cp})_{2}\right]^{0 /+}$ in $1 \mathrm{M} \mathrm{LiTFSI-DME}$ on a GC macroelectrode at $\nu$ from 10 to $1000 \mathrm{mV} / \mathrm{s}$. (B) RandlesSevcik plot of peak current vs $\nu^{1 / 2}$ for the voltammograms in A.

$$
I_{\mathrm{p}}=0.4463 \cdot\left(\frac{F^{3}}{R \cdot T}\right)^{1 / 2} \cdot n^{3 / 2} \cdot A \cdot D_{\mathrm{ox}}^{1 / 2} \cdot C_{\mathrm{ox}} \cdot v^{1 / 2}
$$

where $n$ is the number of electrons, $F$ is Faraday's constant, $A$ is the electrode area, $R$ is the gas constant, and $T$ is the temperature, while $C_{\mathrm{ox}}$ and $D_{\mathrm{ox}}$ are the bulk concentration and diffusion coefficient of the species, respectively. The presented diffusion coefficients in Table 1 were determined using the

Table 1. Diffusion Coefficients for the Six Redox Shuttles Used to Probe the Charge Transfer Through $\mathrm{Li}_{2} \mathrm{O}_{2}$ on GC Electrodes in $1 \mathrm{M}$ LiTFSI-DME at $25{ }^{\circ} \mathrm{C}$

\begin{tabular}{cc} 
redox species & diffusion coefficients $\left[\mathrm{cm}^{2} / \mathrm{s}\right]$ \\
{$\left[\mathrm{Co}(\mathrm{Cp})_{2}\right]^{+}$} & $4.83 \times 10^{-6}$ \\
{$\left[\mathrm{Co}(\mathrm{Cp})_{2}\right]^{0}$} & $5.61 \times 10^{-6}$ \\
{$\left[\mathrm{Fe}(\mathrm{DMCp})_{2}\right]^{+}$} & $6.67 \times 10^{-6}$ \\
{$\left[\mathrm{Fe}(\mathrm{DMCp})_{2}\right]^{0}$} & $6.97 \times 10^{-6}$ \\
{$\left[\mathrm{Fe}(\mathrm{Cp})_{2}\right]^{+}$} & $6.54 \times 10^{-6}$ \\
{$\left[\mathrm{Fe}(\mathrm{Cp})_{2}\right]^{0}$} & $7.90 \times 10^{-6}$ \\
\hline
\end{tabular}

slope found from a least-squares linear fit to peak current data obtained from cyclic voltammetry experiments, such as that depicted in Figures 4B and S3. Assuming $n=1$, the diffusion coefficients for each redox shuttle could be calculated.

All diffusion coefficients are in the range of $5-8 \times 10^{-6}$ due to their relatively similar size, and all positively charged forms have lower values compared to their respective neutral forms due to the increased drag from the $\mathrm{TFSI}^{-}$counterion cloud making the diffusion of the positively charged species diffusion slower. The lowest diffusion coefficients were observed for $\left[\mathrm{Co}(\mathrm{Cp})_{2}\right]^{0 /+}$, which was approximately $18 \%$ lower than that of $\left[\mathrm{Fe}(\mathrm{Cp})_{2}\right]^{0 /+}$, which is in line with observations made in ionic liquids reported by Rogers et al. ${ }^{32}$ To the best of our knowledge, no previous reports are available on the diffusion coefficients of these redox shuttles in $1 \mathrm{M}$ LiTFSI-DME, so in order to verify the diffusion coefficients, one of the most studied redox shuttles, $\left[\mathrm{Fe}(\mathrm{Cp})_{2}\right]^{0}$, was used for comparison with literature values in different nonaqueous solvents. In Figure 5 the diffusion of $\left[\mathrm{Fe}(\mathrm{Cp})_{2}\right]^{0}$ is illustrated as a function of the viscosity of the solution, and here a power decay is observed where the diffusion decreases as the viscosity increases. The diffusion coefficient of $\left[\mathrm{Fe}(\mathrm{Cp})_{2}\right]^{0}$ measured in

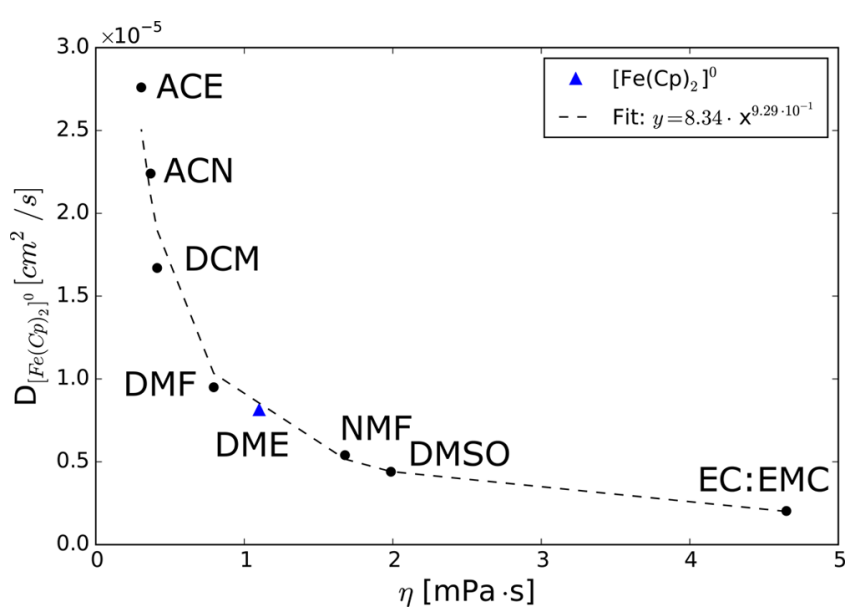

Figure 5. Diffusion coefficient of $\left[\mathrm{Fe}(\mathrm{Cp})_{2}\right]^{0}$ as a function of solvent viscosity. The blue triangle is the diffusion coefficient of $\left[\mathrm{Fe}(\mathrm{Cp})_{2}\right]^{0}$ in 1 M LiTFSI-DME determined by means of Randles-Sevcik. Black dots are literature values, where $\mathrm{ACE}=$ acetone, $\mathrm{ACN}=$ acetonitrile, $\mathrm{DCM}=$ dimethylcarbonate $, \mathrm{DMF}=\mathrm{N}, \mathrm{N}$-dimethylformamide, $\mathrm{DME}=$ 1,2-dimethoxyethane, $\mathrm{NMF}=\mathrm{N}$-methylformaide, $\mathrm{DMSO}=$ dimethyl sulfoxide, EC:EMC = ethylene carbonate:ethyl methyl carbonate. All values were taken from ref 33 except EC:EMC which was taken from ref 34 . The dotted line represents the power-decay fit to the literature values.

1 M LiTFSI-DME aligns into this relationship, thus supporting the validity of the values reported in Table 1.

3.3. Redox Probing of $\mathrm{Li}_{2} \mathrm{O}_{2}$ Surfaces. To investigate the limiting charge transport mechanism as a function of the $\mathrm{Li}_{2} \mathrm{O}_{2}$ thickness, the charge-transfer resistances of the redox shuttles were measured using EIS. Multiple authors ${ }^{3,4,13,17}$ have reported that only conformal films of $\mathrm{Li}_{2} \mathrm{O}_{2}$ grow in strictly anhydrous $1 \mathrm{M}$ LiTFSI-DME, especially on flat small surface area GC disks. Since we carefully excluded water in our experiments, we claim that only dense thin films of $\mathrm{Li}_{2} \mathrm{O}_{2}$ are formed on the GC in our experiments. Our discharge capacities are also similar to those of Viswanathan et al. ${ }^{18}$ in anhydrous DME, indicating that no toroids or higher capacity structures form. The GC electrodes were therefore coated with various thicknesses of $\mathrm{Li}_{2} \mathrm{O}_{2}$ layers prior to the impedance measurements. This was performed by a series of galvanostatic discharges onto different GC electrodes as illustrated in Figure 
6 for the experiments conducted with $\left[\mathrm{Co}(\mathrm{Cp})_{2}\right]^{0 /+}$, while the discharge curves for the $\mathrm{Li}_{2} \mathrm{O}_{2}$ layers used for the probing

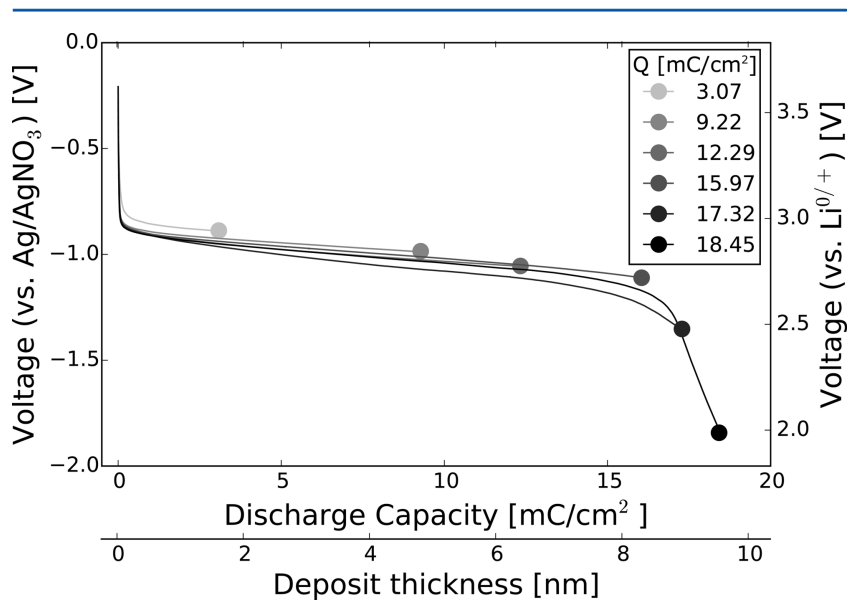

Figure 6. Six galvanostatic discharges were performed on six separate GC electrodes $\left(J=2.5 \mu \mathrm{A} / \mathrm{cm}^{2}\right)$. For calculation of the deposit thickness a surface roughness factor of 2 was assumed for the GC electrodes. Dots mark the terminal capacity of each electrode, at which the redox probing was conducted.

experiments with $\left[\mathrm{Fe}(\mathrm{DMCp})_{2}\right]^{0 /+}$ and $\left[\mathrm{Fe}(\mathrm{Cp})_{2}\right]^{0 /+}$ are illustrated in Figures $\mathrm{S} 4$ and $\mathrm{S} 6$, respectively.

The $\mathrm{Li}_{2} \mathrm{O}_{2}$-coated GC electrode surfaces were probed by EIS in $\mathrm{Ar}$ atmosphere at $E_{1 / 2}$ of each of the redox shuttles. The Nyquist plots for three different depth of discharges using $\left[\mathrm{Co}(\mathrm{Cp})_{2}\right]^{0 /+}$ are illustrated in Figure 7 , while the Nyquist plots for $\left[\mathrm{Fe}(\mathrm{DMCp})_{2}\right]^{0 /+}$ and $\left[\mathrm{Fe}(\mathrm{Cp})_{2}\right]^{0 /+}$ are illustrated in Figures S5 and S7.

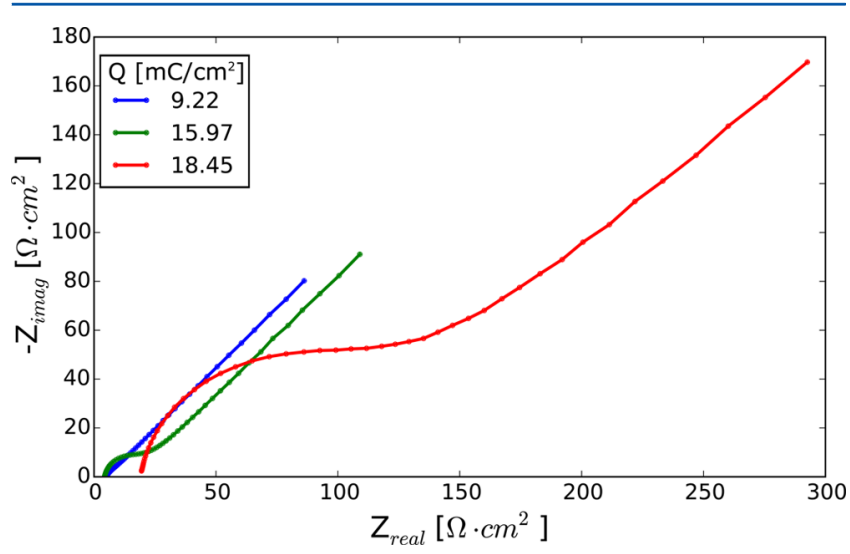

Figure 7. Nyquist plots illustrating the increase in $R_{\mathrm{CT}}$ of $\left[\mathrm{Co}(\mathrm{Cp})_{2}\right]^{0 /+}$ as a function of three different discharge capacities.

These figures illustrate the $R_{\mathrm{CT}}$ varies in the impedance spectra as a function of depth of discharge $\left(\sim \mathrm{Li}_{2} \mathrm{O}_{2}\right.$ thickness $)$ and how it greatly increases close to sudden death. To illustrate the dependency of $R_{\mathrm{CT}}$ as a function depth of discharge ( $\sim \mathrm{Li}_{2} \mathrm{O}_{2}$ thickness), we were interested in quantifying the rate of electron transfer through $\mathrm{Li}_{2} \mathrm{O}_{2}$ using the heterogeneous rate constant $\left(k^{0}\right)$ since this also made it possible to correct the measured $R_{\mathrm{CT}}$ for concentration variations of the redox shuttle in solution. These variations occurred since 5-6 GC electrodes were needed to obtain a sufficient mapping of the discharge. The electrochemical cell, as sketched in Figure 2, contained only three GC electrodes; thus, two separate experiments were performed, giving rise to small concentration deviations between the two experiments.

The $R_{\mathrm{CT}}$ was determined by fitting a Randles equivalent circuit to the data that describes a heterogeneous charge transfer and semi-infinite linear diffusion, and the complex nonlinear least-squares fitting was carried out using a software package written in Python. ${ }^{35}$ Data validation was carried out by using the linearized Kramers-Kronig test (KK) suggested by Boukamp. $^{36}$ All data used for determination of $R_{\mathrm{CT}}$ here displayed residuals of less than $\pm 1 \%$ using this test, indicating good adherence to the requirements of causality, linearity, stability, and finiteness of the data. The resulting Nyquist and Bode plots and the equivalent circuit model used are shown in Figure 8 for $\left[\mathrm{Co}(\mathrm{Cp})_{2}\right]^{0 /+}$, while the Nyquist plots for $\left[\mathrm{Fe}(\mathrm{DMCp})_{2}\right]^{0 /+}$ and $\left[\mathrm{Fe}(\mathrm{Cp})_{2}\right]^{0 /+}$ are illustrated in Figures S5 and S7.

Figure 8 depicts the EIS spectrum for the $15.97 \mathrm{mC} / \mathrm{cm}^{2}$ discharged electrode with $\left[\mathrm{Co}(\mathrm{Cp})_{2}\right]^{0 /+}$ as the redox shuttle and the corresponding fitted equivalent circuit, where it is evident that the model describes charge transfer and the following diffusion well. At pristine electrodes the $R_{\mathrm{CT}}$ of the three redox shuttles could not be detected by EIS as the spectra were completely dominated by the diffusion impedance. In fact, these outer-sphere redox shuttles have very fast heterogeneous exchange rate constants causing the $\mathrm{e}^{-}$transfer to be so rapid that the electronics used in measuring these systems simply is not fast enough. This is likely the reason for the lack of data in the literature of the $k^{0}$ on pristine electrodes for these redox shuttles. A few authors have reported $k^{0}$ 's at pristine electrode of larger and more sluggish redox shuttles, such as the 7,7,8,8tetracyanoquinodimethane, using specialized higher harmonic techniques or steady-state voltammetry from microelectrodes. $^{37,38}$ A similar study using steady-state voltammetry recorded with a microelectrode was conducted here in the hope of obtaining $k^{0}$ 's of the three redox shuttles at pristine surfaces, but as Aoki et al. ${ }^{37}$ also concluded, the solution resistance and currents related to double-layer charging of the microelectrode were too great to obtain reliable results and therefore not included here. Aoki et al. suggests that $\left[\mathrm{Fe}(\mathrm{Cp})_{2}\right]^{0 /+}$ and similar molecules have $k^{0}$ 's greater than 10 $\mathrm{cm} / \mathrm{s}$ at pristine Pt surfaces. ${ }^{37}$ Assuming $k^{0}$ of $10 \mathrm{~cm} / \mathrm{s}$, we can estimate that, as described in the SI, the characteristic frequency for the oxidation/reduction of $\left[\mathrm{Co}(\mathrm{Cp})_{2}\right]^{0 /+}$ is approximately 5 $\mathrm{MHz}$ and well beyond the practical frequency range of our equipment.

To illustrate the dependency of the charge transport mechanism as a function of depth of discharge $\left(\sim \mathrm{Li}_{2} \mathrm{O}_{2}\right.$ thickness) we determined the $k^{0}$ for electron exchange between the glassy carbon electrode and the different redox shuttles in solution with $\mathrm{Li}_{2} \mathrm{O}_{2}$ sandwiched in between, Figure 1. The relationship between $k^{0}$ and $\mathrm{R}_{\mathrm{CT}}$ is given in eq 2 . $^{28,31}$

$$
k^{0}=\frac{R \cdot T}{n^{2} \cdot F^{2} \cdot R_{C T} \cdot A \cdot C_{\mathrm{ox}}^{1-\alpha} \cdot C_{\mathrm{red}}^{\alpha}}
$$

The fourth working electrode in solution, Figure 2, was an $\mathrm{Au}$ electrode that was used to measure the concentration of each redox species in solution by cyclic voltammetry at 100 $\mathrm{mV} / \mathrm{s}$ in Ar. From the peak currents it was possible to determine the precise concentrations by rearranging eq 1 . 

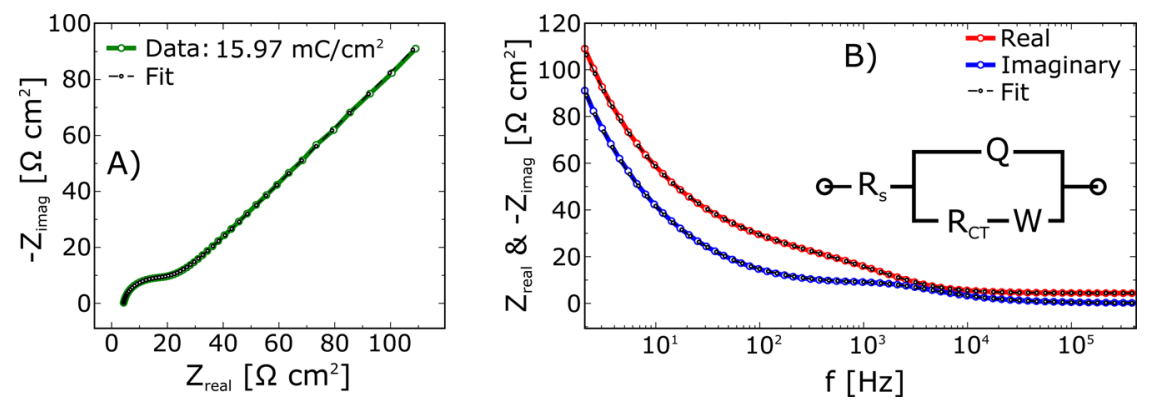

Figure 8. Nyquist plot (A) and Bode-like plot (B) for the terminal discharge capacity of $15.97 \mathrm{mC} / \mathrm{cm}^{2}$ with $\left[\mathrm{Co}(\mathrm{Cp})_{2}\right]^{0 /+}$ in solution corresponding to the green spectrum illustrated in Figure 7 . The equivalent circuit used to model and extract $R_{\mathrm{CT}}$ is inserted into $\mathrm{B}$.

$$
C_{\mathrm{ox}}=\frac{I_{\mathrm{p}}^{\mathrm{ox}}}{D_{\mathrm{ox}}^{1 / 2} \cdot A \cdot 0.4463 \cdot n^{3 / 2} \cdot v^{1 / 2} \cdot\left(\frac{F^{3}}{R \cdot T}\right)^{1 / 2}}
$$

In eq 3 , the determined diffusion coefficients were used in the determinations of $C_{\mathrm{ox}}$ and $C_{\text {red }}$ and consequently the $k^{0}$ 's. The concentration correction of the redox shuttles that was used in the calculation of $k^{0}$ clearly proved to be significant when compared to the exchange current density $\left(j_{0}\right)$, which does not take $C_{\text {ox }}$ and $C_{\text {red }}$ into account. This is illustrated in Figure S8, where a shift in $j_{0}$ is clearly observed between two separate experiments, but it is also evident that this shift was caused by a concentration difference of $\left[\mathrm{Co}(\mathrm{Cp})_{2}\right]^{0 /+}$ between the experiments as this was corrected for by $k^{0}$.

The resulting plot of $k^{0}$ 's as a function of depth of discharge and $\mathrm{Li}_{2} \mathrm{O}_{2}$ thickness is illustrated in Figure 9, and here the redox shuttles acted as the charge source/sink, $\mathrm{Li}_{2} \mathrm{O}_{2}$ as the insulator, and the $\mathrm{GC}$ electrode as the charge source/sink.

For $\left[\mathrm{Co}(\mathrm{Cp})_{2}\right]^{0 /+}$ and $\left[\mathrm{Fe}(\mathrm{DMCp})_{2}\right]^{0 /+}$ we see an exponential decrease in $k^{0}$ with a discharge capacity that mirrors the exponential sudden death in the $\mathrm{Li}-\mathrm{O}_{2}$ with discharge capacity. This shows that the origin of the sudden death is due to charge transport limitations. Since $E_{1 / 2}$ of

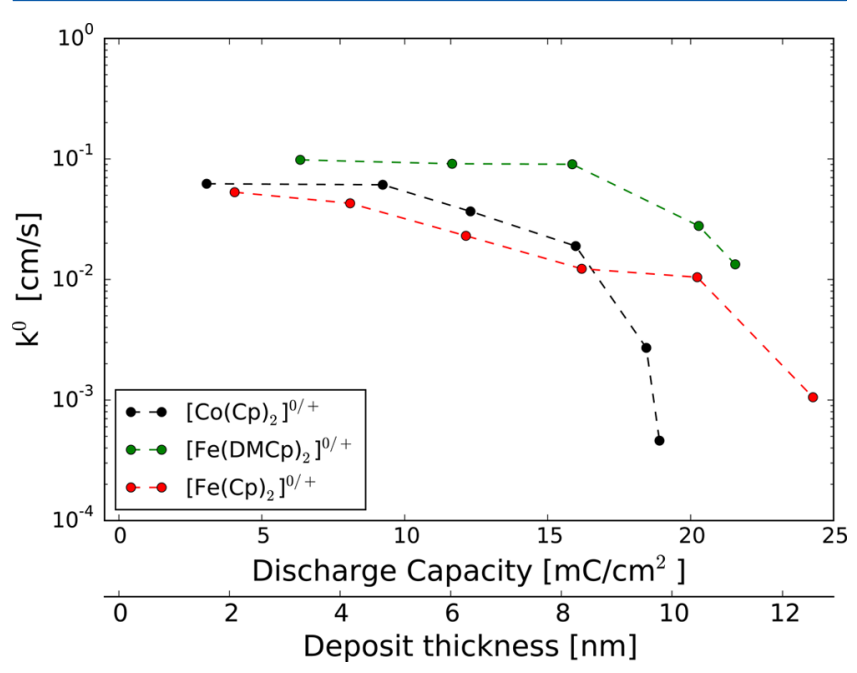

Figure 9. Heterogeneous rate constant illustrated as a function of discharge capacity and $\mathrm{Li}_{2} \mathrm{O}_{2}$ thickness (thickness was calculated assuming that the $\mathrm{Li}_{2} \mathrm{O}_{2}$ grows as a dense thin film and that the surface roughness of the electrode was a factor of 2$). k^{0}$ 's were calculated from $R_{\mathrm{CT}}$ obtained from the EIS. The three redox shuttles were probed at their respective $E_{1 / 2}$ in $\mathrm{Ar}$, e.g., $\left[\mathrm{Co}(\mathrm{Cp})_{2}\right]^{0 /+}$ at $2.35 \mathrm{~V},[\mathrm{Fe}-$

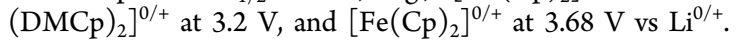

$\left[\mathrm{Co}(\mathrm{Cp})_{2}\right]^{0 /+}$ and $\left[\mathrm{Fe}(\mathrm{DMCp})_{2}\right]^{0 /+}$ both are inside the band gap of $\mathrm{Li}_{2} \mathrm{O}_{2}$, as illustrated in Figure 1, electronic conduction is likely dominated by a mechanism of hole transport. This transport could be via tunneling ${ }^{18,24}$ or via thermally excited hole polarons. ${ }^{23,24,39-41}$

We believe that tunneling is the dominant mechanism of hole charge transport in the experiments reported here since relatively high current densities are involved in the impedance measurements $\left(>9 \mu \mathrm{A} / \mathrm{cm}^{2}\right)$ and since this mechanism fits a wide range of experimental results, e.g., the existence of discharge sudden deaths and its dependence on current and temperature, asymmetry between discharge and charge sudden death, etc. ${ }^{1,24}$ We do note, however, that additional charge transport from hole polarons can also contribute at low current densities $\left(<1 \mu \mathrm{A} / \mathrm{cm}^{2}\right){ }^{24} \mathrm{~A}$ very recent extended hole polaron model by Radin et al. ${ }^{41}$ with some adjustable parameters also seems to be able to fit some of the observed aspects of sudden death.

One feature that should be noted in Figure 9 is the difference in $\mathrm{Li}_{2} \mathrm{O}_{2}$ thickness/capacity between $\left[\mathrm{Co}(\mathrm{Cp})_{2}\right]^{0 /+}$ and $[\mathrm{Fe}-$ $\left.(\mathrm{DMCp})_{2}\right]^{0 /+}$, with an extended discharge capacity for $\left[\mathrm{Fe}(\mathrm{DMCp})_{2}\right]^{0 /+}$. We interpret this difference as due to the very different hole transport at 0.9 and $0.05 \mathrm{~V}$ relative to the $\mathrm{VB}$, respectively. The predictions of charge transport at $2 \mu \mathrm{A} /$ $\mathrm{cm}^{2}$ current density as a function of the $\mathrm{Li}_{2} \mathrm{O}_{2}$ film thickness from a simple semiclassical tunneling model of charge transport and based on assuming trapezoidal barrier shapes ${ }^{24}$ is presented in Figure 10. Therefore, the results of Figure 9 are qualitatively

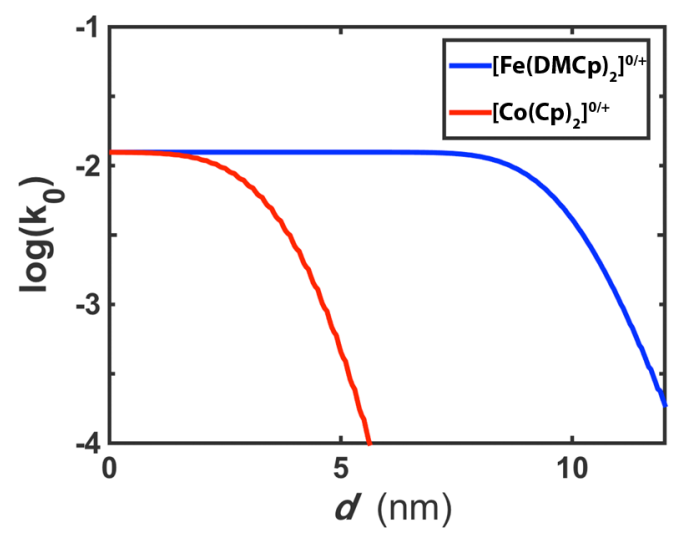

Figure 10. Tunneling charge transport $\mathrm{Li}_{2} \mathrm{O}_{2}$ films as a function of film thickness $d$ assuming the energy levels given in Figure 1. Since the absolute value of $k^{0}$ at $d=0$ depends on the exchange current densities of the two different redox species (and is unknown), it is simply scaled to be in rough agreement with experiment. 
consistent with hole tunneling. We anticipate that if hole polarons were the dominant charge transport mechanism, there should be much larger differences between the $\left[\mathrm{Co}(\mathrm{Cp})_{2}\right]^{0 /+}$ and the $\left[\mathrm{Fe}(\mathrm{DMCp})_{2}\right]^{0 /+}$ capacities (at which the chargetransfer attenuation becomes significant) since the polaron population and hence conductivity depends exponentially on the energy of the polaron relative to the VB. Since the bulk polaron energy is required to be the same as the electrochemical Fermi energy, i.e., the $\left[\mathrm{Co}(\mathrm{Cp})_{2}\right]^{0 /+}$ and $[\mathrm{Fe}-$ $\left.(\mathrm{DMCp})_{2}\right]^{0 /+}$ redox potentials, we would anticipate significantly larger differences. Of course, band bending at the interfaces of the thin films could lessen this effect. ${ }^{41}$

In this figure, the barrier thickness is given by a nearly uniform $\mathrm{Li}_{2} \mathrm{O}_{2}$ film thickness $d$ (Gaussian roughness of $0.5 \mathrm{~nm}$ ). This is in reasonable qualitative agreement with the experimental observations in Figure 9, although the difference between $\left[\mathrm{Co}(\mathrm{Cp})_{2}\right]^{0 /+}$ and $\left[\mathrm{Fe}(\mathrm{DMCp})_{2}\right]^{0 /+}$ is overemphasized. We suspect this may be due to uncertainties in the exact barrier heights for tunneling or due to contributions from hole polaron charge transport.

The experiments with $\left[\mathrm{Fe}(\mathrm{Cp})_{2}\right]^{0 /+}$ need a different explanation. The relationship between $k^{0}$ and the thickness of $\mathrm{Li}_{2} \mathrm{O}_{2}$ (or discharge capacity) almost exhibit a linear relationship. The electronic conduction through $\mathrm{Li}_{2} \mathrm{O}_{2}$ at this potential (3.68 $\mathrm{V}$ vs $\mathrm{Li}^{0 /+}$ ) can therefore not be assigned to hole tunneling, since the potential of $\left[\mathrm{Fe}(\mathrm{Cp})_{2}\right]^{0 /+}\left(3.68 \mathrm{~V} \mathrm{vs} \mathrm{Li}^{0 /+}\right)$ is well inside the $\mathrm{VB}$ of $\mathrm{Li}_{2} \mathrm{O}_{2}\left(3.25 \mathrm{~V}\right.$ vs $\left.\mathrm{Li}^{0 /+}\right)$, and thereby there is no need for hole tunneling, since electron (hole) conduction though $\mathrm{Li}_{2} \mathrm{O}_{2}$ should be possible via the VB. Instead, we hypothesize that the observed relationship between $k^{0}$ and discharge capacity $\left(\sim \mathrm{Li}_{2} \mathrm{O}_{2}\right.$ thickness), in the case of $\left[\mathrm{Fe}(\mathrm{Cp})_{2}\right]^{0 /+}$, is a consequence of the increasing $R_{\mathrm{CT}}$ as the $\mathrm{Li}_{2} \mathrm{O}_{2}$ layer thickens but that the difference in $k^{0}$ attenuation and lack of exponential decay (which is the case for tunneling) is due to the charging potential at which $\left[\mathrm{Fe}(\mathrm{Cp})_{2}\right]^{0 /+}$ was probed. At this potential, $\mathrm{Li}_{2} \mathrm{O}_{2}$ was oxidized for the entire duration of the EIS measurement (approximately $3.5 \mathrm{~min}$ ) while probing the surface. Note that, Viswanathan et al. ${ }^{18}$ suggested that $\left[\mathrm{Fe}(\mathrm{Cp})_{2}\right]^{0 /+}$ probed hole tunneling, but with better knowledge of energy level alignments provided here, this is unlikely. Therefore, the $k^{0}$ for $\left[\mathrm{Fe}(\mathrm{Cp})_{2}\right]^{0 /+}$ is a mixture of both hole transport through $\mathrm{Li}_{2} \mathrm{O}_{2}$ via some ohmic process, $\mathrm{Li}_{2} \mathrm{O}_{2}$ oxidation and possibly $\mathrm{LiRCO}_{3}$ electrochemical formation, which has been shown to form at these potentials in this specific electrolyte. ${ }^{42-44}$

\section{CONCLUSION}

In this paper, we performed detailed electrochemical experiments to probe the fundamental limiting processes of $\mathrm{e}^{-}$ transfer through the main deposition product in the $\mathrm{Li}-\mathrm{O}_{2}$ battery, $\mathrm{Li}_{2} \mathrm{O}_{2}$. The experiments utilized three outer-sphere redox shuttles to probe the charge transfer through electrochemically grown $\mathrm{Li}_{2} \mathrm{O}_{2}$ on glassy carbon electrodes.

The results show (i) that the attenuation of the heterogeneous rate constants for $\left[\mathrm{Co}(\mathrm{Cp})_{2}\right]^{0 /+}$ and $[\mathrm{Fe}-$ $\left.(\mathrm{DMCp})_{2}\right]^{0 /+}$ displays an exponential decay caused by hole charge transport at the potentials probed as a function of the $\mathrm{Li}_{2} \mathrm{O}_{2}$ thickness (discharge capacity) and (ii) a clear dependency on the potential probed and the $\mathrm{Li}_{2} \mathrm{O}_{2}$ thickness (discharge capacity) obtained. We suggest that this results from different hole tunneling barriers at which the charge transfer through $\mathrm{Li}_{2} \mathrm{O}_{2}$ was probed; hence, the smaller the hole tunneling barrier (or the greater the polaron/hole conductiv- ity), the greater the thickness at which significant attenuation of the heterogeneous exchange rate takes place. The findings reported here thus further confirm that sudden death in the $\mathrm{Li}-$ $\mathrm{O}_{2}$ battery occurs when the charge transport can no longer support the applied electrochemical current.

\section{ASSOCIATED CONTENT}

\section{S Supporting Information}

The Supporting Information is available free of charge on the ACS Publications website at DOI: 10.1021/acs.jpcc.5b08757.

Synthesis and characterization of $\left[\mathrm{Fe}(\mathrm{DMCp})_{2}\right]^{0 /+}$, supporting figures and tables including voltammetry results of the three redox shuttles, water impurities, impact of redox shuttle concentration on $j_{0}$, and characteristic frequency for the redox shuttles on pristine electrodes (PDF)

\section{AUTHOR INFORMATION}

\section{Corresponding Author}

*Phone: +45 467758 87. E-mail: johh@dtu.dk.

\section{Notes}

The authors declare no competing financial interest.

\section{ACKNOWLEDGMENTS}

The authors gratefully acknowledge financial support from the ReLiable project (project no. 11-116792) funded by the Danish Council for Strategic Research, Program Commission on Sustainable Energy and Environment. Dr. Wesley Browne is acknowledged for helpful advice regarding the synthesis and purification of metallocenes.

\section{REFERENCES}

(1) Luntz, A. C.; McCloskey, B. D. Nonaqueous Li-Air Batteries: A Status Report. Chem. Rev. 2014, 114, 11721.

(2) Kundu, D.; Black, R.; Jämstorp Berg, E.; Nazar, L. F. A Highly Active Nanostructured Metallic Oxide Cathode for Aprotic $\mathrm{Li}-\mathrm{O}_{2}$ Batteries. Energy Environ. Sci. 2015, 8 (4), 1292-1298.

(3) Aetukuri, N. B.; McCloskey, B. D.; García, J. M.; Krupp, L. E.; Viswanathan, V.; Luntz, A. C. Solvating Additives Drive SolutionMediated Electrochemistry and Enhance Toroid Growth in NonAqueous Li-O2 Batteries. Nat. Chem. 2014, 7 (1), 50-56.

(4) Schwenke, K. U.; Metzger, M.; Restle, T.; Piana, M.; Gasteiger, H. A. The Influence of Water and Protons on $\mathrm{Li}_{2} \mathrm{O}_{2}$ Crystal Growth in Aprotic Li-O $\mathrm{O}_{2}$ Cells. J. Electrochem. Soc. 2015, 162 (4), A573-A584.

(5) Younesi, R.; Veith, G. M.; Johansson, P.; Edström, K.; Vegge, T. Lithium Salts for Advanced Lithium Batteries: $\mathrm{Li}-$ metal, $\mathrm{Li}-\mathrm{O}_{2}$, and Li-S. Energy Environ. Sci. 2015, 8 (7), 1905-1922.

(6) Younesi, R.; Hahlin, M.; Björefors, F.; Johansson, P.; Edström, K. $\mathrm{Li}-\mathrm{O}_{2}$ Battery Degradation by Lithium Peroxide $\left(\mathrm{Li}_{2} \mathrm{O}_{2}\right)$ : A Model Study. Chem. Mater. 2013, 25 (1), 77-84.

(7) Younesi, R.; Norby, P.; Vegge, T. A New Look at the Stability of Dimethyl Sulfoxide and Acetonitrile in $\mathrm{Li}^{-\mathrm{O}_{2}}$ Batteries. ECS Electrochem. Lett. 2014, 3 (3), A15-A18.

(8) Das, S.; Højberg, J.; Knudsen, K. B.; Younesi, R.; Johansson, P.; Norby, P.; Vegge, T. Instability of Ionic Liquid-Based Electrolytes in $\mathrm{Li}-\mathrm{O}_{2}$ Batteries. J. Phys. Chem. C 2015, 119, 18084.

(9) McCloskey, B. D.; Speidel, A.; Scheffler, R.; Miller, D. C.; Viswanathan, V.; Hummelshøj, J. S.; Nørskov, J. K.; Luntz, A. C. Twin Problems of Interfacial Carbonate Formation in Nonaqueous $\mathrm{Li}-\mathrm{O} 2$ Batteries. J. Phys. Chem. Lett. 2012, 3 (8), 997-1001.

(10) Gallant, B. M.; Mitchell, R. R.; Kwabi, D. G.; Zhou, J.; Zuin, L.; Thompson, C. V.; Shao-Horn, Y. Chemical and Morphological Changes of Li- $\mathrm{O}_{2}$ Battery Electrodes upon Cycling. J. Phys. Chem. C 2012, 116 (39), 20800-20805. 
(11) Ottakam Thotiyl, M. M.; Freunberger, S. A.; Peng, Z.; Bruce, P. G. The Carbon Electrode in Nonaqueous $\mathrm{Li}-\mathrm{O}_{2}$ Cells. J. Am. Chem. Soc. 2013, 135 (1), 494-500.

(12) Black, R.; Oh, S. H.; Lee, J.-H.; Yim, T.; Adams, B.; Nazar, L. F. Screening for Superoxide Reactivity in $\mathrm{Li}_{2} \mathrm{O}_{2}$ Batteries: Effect on $\mathrm{Li}_{2} \mathrm{O}_{2} / \mathrm{LiOH}$ Crystallization. J. Am. Chem. Soc. 2012, 134 (6), 29022905

(13) Johnson, L.; Li, C.; Liu, Z.; Chen, Y.; Freunberger, S. A.; Ashok, P. C.; Praveen, B. B.; Dholakia, K.; Tarascon, J.-M.; Bruce, P. G. The Role of $\mathrm{LiO}_{2}$ Solubility in $\mathrm{O}_{2}$ Reduction in Aprotic Solvents and Its Consequences for $\mathrm{Li}-\mathrm{O}_{2}$ Batteries. Nat. Chem. 2014, 6 (12), 10911099

(14) Burke, C. M.; Pande, V.; Khetan, A.; Viswanathan, V.; McCloskey, B. D. Enhancing Electrochemical Intermediate Solvation through Electrolyte Anion Selection to Increase Nonaqueous Li-O2 Battery Capacity. Proc. Natl. Acad. Sci. U. S. A. 2015, 112, 9293.

(15) Khetan, A.; Luntz, A.; Viswanathan, V. Trade-Offs in Capacity and Rechargeability in Nonaqueous $\mathrm{Li}-\mathrm{O}_{2}$ Batteries: Solution-Driven Growth versus Nucleophilic Stability. J. Phys. Chem. Lett. 2015, 6 (7), 1254-1259.

(16) Højberg, J.; McCloskey, B. D.; Hjelm, J.; Vegge, T.; Johansen, K.; Norby, P.; Luntz, A. C. An Electrochemical Impedance Spectroscopy Investigation of the Overpotentials in $\mathrm{Li}-\mathrm{O}_{2}$ Batteries. ACS Appl. Mater. Interfaces 2015, 7, 4039-4047.

(17) Albertus, P.; Girishkumar, G.; McCloskey, B.; Sánchez-Carrera, R. S.; Kozinsky, B.; Christensen, J.; Luntz, A. C. Identifying Capacity Limitations in the Li/Oxygen Battery Using Experiments and Modeling. J. Electrochem. Soc. 2011, 158 (3), A343-A351.

(18) Viswanathan, V.; Thygesen, K. S.; Hummelshøj, J. S.; Nørskov, J. K.; Girishkumar, G.; McCloskey, B. D.; Luntz, A. C. Electrical Conductivity in $\mathrm{Li}_{2} \mathrm{O}_{2}$ and Its Role in Determining Capacity Limitations in Non-Aqueous $\mathrm{Li}^{-} \mathrm{O}_{2}$ Batteries. J. Chem. Phys. 2011, 135 (21), 214704-214704-10.

(19) Noviandri, I.; Brown, K. N.; Fleming, D. S.; Gulyas, P. T.; Lay, P. A.; Masters, A. F.; Phillips, L. The Decamethylferrocenium/ Decamethylferrocene Redox Couple: A Superior Redox Standard to the Ferrocenium/Ferrocene Redox Couple for Studying Solvent Effects on the Thermodynamics of Electron Transfer. J. Phys. Chem. B 1999, 103 (32), 6713-6722.

(20) Richardson, J. N. Heterogeneous Electron-Transfer Dynamics of Decamethylferrocene from 130 to 181 K. J. Phys. Chem. 1994, 98 (50), 13396.

(21) Bard, A. J.; Garcia, E.; Kukharenko, S.; Strelets, V. V. Electrochemistry of Metallocenes at Very Negative and Very Positive Potentials. Electrogeneration of 17-Electron $\mathrm{Cp}_{2} \mathrm{Co}^{2+}$, 21-Electron $\mathrm{Cp}_{2} \mathrm{Co}+$, and 22-Electron $\mathrm{Cp}_{2} \mathrm{Ni}^{2-}$ Species. Inorg. Chem. 1993, 32 (16), $3528-3531$.

(22) Radin, M. D.; Tian, F.; Siegel, D. J. Electronic Structure of $\mathrm{Li}_{2} \mathrm{O}_{2}$ \{0001\} Surfaces. J. Mater. Sci. 2012, 47 (21), 7564-7570.

(23) Varley, J. B.; Viswanathan, V.; Luntz, A. C. Lithium and oxygen vacancies and their role in $\mathrm{Li} 2 \mathrm{O} 2$ charge transport in $\mathrm{Li}-\mathrm{O}_{2}$ batteries. Energy Environ. Sci. 2014, 7, 720-727.

(24) Luntz, A. C.; Viswanathan, V.; Voss, J.; Varley, J. B.; Nørskov, j. K.; Scheffler, R.; Speidel, A. Tunneling and Polaron Charge Transport through $\mathrm{Li}_{2} \mathrm{O}_{2}$ in $\mathrm{Li}-\mathrm{O}_{2}$ Batteries. J. Phys. Chem. Lett. 2013, 4 (20), 3494-3499.

(25) Kang, J.; Jung, Y. S.; Wei, S.-H.; Dillon, A. C. Implications of the Formation of Small Polarons in $\mathrm{Li} 2 \mathrm{O} 2$ for Li-Air Batteries. Phys. Rev. B: Condens. Matter Mater. Phys. 2012, 85 (3), 035210.

(26) Garcia-Lastra, J. M.; Myrdal, J. S. G.; Christensen, R.; Thygesen, K. S.; Vegge, T. DFT+U Study of Polaronic Conduction in Li2O2 and $\mathrm{Li}_{2} \mathrm{CO}_{3}$ : Implications for Li-Air Batteries. J. Phys. Chem. C 2013, 117 (11), 5568-5577.

(27) Mansfeld, F.; Lin, S.; Chen, Y. C.; Shih, H. Minimization of High-Frequency Phase Shifts in Impedance Measurements. J. Electrochem. Soc. 1988, 135 (4), 906-907.

(28) Lasia, A. Electrochemical Impedance Spectroscopy and Its Applications. In Modern Aspects of Electrochemistry; Conway, B. E., Bockris, J. O., White, R. E., Eds.; Springer: New York, 2002.
(29) Sawyer, D. T.; Sobkowiak, A.; Roberts, J. L.; Sawyer, D. T. Electrochemistry for Chemists; Wiley: New York, 1995.

(30) Gunasekara, I.; Mukerjee, S.; Plichta, E. J.; Hendrickson, M. A.; Abraham, K. M. A Study of the Influence of Lithium Salt Anions on Oxygen Reduction Reactions in Li-Air Batteries. J. Electrochem. Soc. 2015, 162 (6), A1055-A1066.

(31) Bard, A. J.; Faulkner, L. R. Electrochemical Methodes: Fundamentals and Applications, 2nd ed.; John Wiley \& Sons, Inc.: New York, 2001.

(32) Rogers, E. I.; Silvester, D. S.; Poole, D. L.; Aldous, L.; Hardacre, C.; Compton, R. G. Voltammetric Characterization of the Ferrocenel Ferrocenium and CobaltoceniumlCobaltocene Redox Couples in RTILs. J. Phys. Chem. C 2008, 112 (7), 2729-2735.

(33) CRC Handbook of Chemistry and Physics; CRC Press: Boca Raton, FL, 2014-2015.

(34) Laoire, C. O.; Plichta, E.; Hendrickson, M.; Mukerjee, S.; Abraham, K. M. Electrochemical Studies of Ferrocene in a Lithium Ion Conducting Organic Carbonate Electrolyte. Electrochim. Acta 2009, 54 (26), 6560-6564.

(35) Graves, C. RAVDAV Data Analysis Software, Version 0.9.7; Technical University of Denmark: Roskilde, Denmark, 2012.

(36) Boukamp, B. A. A Linear Kronig-Kramers Transform Test for Immittance Data Validation. J. Electrochem. Soc. 1995, 142 (6), 18851894

(37) Aoki, K. J.; Zhang, C.; Chen, J.; Nishiumi, T. Heterogeneous Reaction Rate Constants by Steady-State Microelectrode Techniques and Fast Scan Voltammetry. J. Electroanal. Chem. 2013, 706, 40-47.

(38) Bano, K.; Nafady, A.; Zhang, J.; Bond, A. M. Inam-ul-Haque. Electrode Kinetics Associated with Tetracyanoquinodimethane (TCNQ), $\mathrm{TCNQ}^{-}$, and $\mathrm{TCNQ}^{2-}$ Redox Chemistry in Acetonitrile As Determined by Analysis of Higher Harmonic Components Derived from Fourier Transformed Large Amplitude Ac Voltammetry. J. Phys. Chem. C 2011, 115 (49), 24153-24163.

(39) Mekonnen, Y. S.; Garcia-Lastra, J. M.; Hummelshøj, J. S.; Jin, C.; Vegge, T. Role of $\mathrm{Li}_{2} \mathrm{O}_{2} @ \mathrm{Li}_{2} \mathrm{CO}_{3}$ Interfaces on Charge Transport in Nonaqueous Li-Air Batteries. J. Phys. Chem. C 2015, 119 (32), $18066-18073$.

(40) Mo, Y.; Ong, S. P.; Ceder, G. First-Principles Study of the Oxygen Evolution Reaction of Lithium Peroxide in the Lithium-Air Battery. Phys. Rev. B: Condens. Matter Mater. Phys. 2011, 84 (20), 205446.

(41) Radin, M. D.; Monroe, C. W.; Siegel, D. J. Impact of SpaceCharge Layers on Sudden Death in $\mathrm{Li} / \mathrm{O}_{2}$ Batteries. J. Phys. Chem. Lett. 2015, 6, 3017-3022.

(42) McCloskey, B. D.; Bethune, D. S.; Shelby, R. M.; Girishkumar, G.; Luntz, A. C. Solvents' Critical Role in Nonaqueous LithiumOxygen Battery Electrochemistry. J. Phys. Chem. Lett. 2011, 2 (10), $1161-1166$

(43) McCloskey, B. D.; Valery, A.; Luntz, A. C.; Wallraff, G. M.; Garcia, J. M.; Mori, T.; Krupp, L. E. Combining Accurate $\mathrm{O}_{2}$ and $\mathrm{Li}_{2} \mathrm{O}_{2}$ Assays to Separate Discharge and Charge Stability Limitations in Nonaqueous $\mathrm{Li}-\mathrm{O}_{2}$ Batteries. J. Phys. Chem. Lett. 2013, 4 (17), 29892993.

(44) Højberg, J.; Knudsen, K. B.; Hjelm, J.; Vegge, T. Reactions and SEI Formation during Charging of $\mathrm{Li}_{-} \mathrm{O}_{2}$ Cells. ECS Electrochem. Lett. 2015, 4 (7), A63-A66. 